\title{
Students' Speaking Skills in Mathematics Classroom Using Lesson Study and Open Approach
}

\author{
Phattaraphong Kunseeda1, Maitree Inprasitha ${ }^{2}$, Narumon Changsri², Anake Sudjamnong ${ }^{3}$ \\ ${ }^{1}$ Doctoral Program in Mathematics Education, Faculty of Education, Khon Kaen University, Khon Kaen, Thailand \\ ${ }^{2}$ Center for Research in Mathematics Education (CRME), KhonKaen University, Khon Kaen, Thailand \\ ${ }^{3}$ Mathematics and Statistics Program, Faculty of Science and Technology, Suratthani Rajabhat University, Suratthani, Thailand \\ Email: Phattaraphong_Kunseeda@hotmail.com, inprasitha_crme@kku.ac.th, Changsri_crme@kku.ac.th, \\ sud_anake@hotmail.com
}

How to cite this paper: Kunseeda, P., Inprasitha, M., Changsri, N., \& Sudjamnong, A. (2019). Students' Speaking Skills in Mathematics Classroom Using Lesson Study and Open Approach. Creative Education, 10, 1702-1712.

https://doi.org/10.4236/ce.2019.107121

Received: May 20, 2019

Accepted: July 28, 2019

Published: July 31, 2019

Copyright $\odot 2019$ by author(s) and Scientific Research Publishing Inc. This work is licensed under the Creative Commons Attribution International License (CC BY 4.0).

http://creativecommons.org/licenses/by/4.0/

\begin{abstract}
The purpose of this research was to investigate students' speaking skills in mathematics classroom using Lesson Study and Open Approach. The target group comprised twenty-nine students in a first-grade mathematics classroom using open approach as a teaching approach. During the 2018 schoolyear, data was collected used a questionnaire based on framework of Isoda, Morita, and Nobuchi (2009 cited in Inprasitha, 2014) and classroom observation in the context of classroom using lesson study and open approach based on Inprasitha $(2010,2011)$. Research found that students' speaking skills in mathematics classroom using open approach at the following levels: level one included students who spoke with a clear voice (17.24\%); level two included students who presented their ideas step by step (51.72\%); level three included students who complemented their speech with pictures or tables to explain their reason (24.13\%); level four included students who spoke connections their reasoning and the subject of what they previously learned (3.45\%); and level five included students who provided explanations with useful information that was easy to understand, observing the condition of their peers when they spoke (3.45\%).
\end{abstract}

\section{Keywords}

Speaking Skills, Mathematics Classroom, Lesson Study, Open Approach

\section{Introduction}

Teaching and assessment of twenty-first century skills originate in the widely 
that will demand a very different set of skills and competencies from people in order to function effectively at work (Ananiadou \& Claro, 2009). Cedefop (2008) defined a skill as the ability to perform tasks and solved problems. Levy and Murnane (2004 cited in Inprasitha, 2016) stated that thinking and communication skills are the new skills in life in the twenty-first century, which students must learn by themselves as teacher is unable to provide instruction. The National Council of Teachers of Mathematics (2000) proposed ideas of communication, in classrooms where students are challenged to think and reason about mathematics, communication is an essential feature as students express the results of their thinking orally and in writing. Pourhossein (2014) stated that the communicative process involves interaction between at least two people who shared a list of signs and semiotic rules. For problem solving in a classroom using open approach as a teaching approach, students were shown the process of mathematical problem solving (Inprasitha et al., 2003). Communication was an important role in the preparation of students as lifelong learners and members of a larger community with a voice and a sense of responsibility to others (Ananiadou \& Claro, 2009). So that, Inprasitha (2014) presented it as follows: in a classroom in which teachers attempted stimulation of their students to express how to solve the problem and represented their ideas by word, these were basic skills that can be derived from learning skills. Students considered speaking to be the most difficult skill since it required great courage and preparation (Gani et al., 2015). Lee (2006) explained as follows: students could see and hear about what the others spoke, which considered of conversation between students and extended to the work by small groups. Strategies for developing speaking skills are an important part of the learning process with teachers assisting students in learning to speak (NCLRC, 2004). Isoda, Morita and Nobuchi (2009 cited in Inprasitha, 2014) advised teachers' use of questionnaires concerning their students' speaking skills to evaluate their classroom. Nombre et al. (2012) stated that speaking is one of the most difficult skills students face.

Speaking is the ability to express or exchange thoughts through language (Mart, 2012). It is essential for teachers to attempted to understand the students' ideas and the students' mathematical development up to a higher level and allow students to explain their ideas through language, mathematical symbols (Inprasitha, 2004) and consistent with the National Council of Teachers of Mathematics (NCTM) (2000) stated that communication about mathematical concepts is a way for students to make meaningful words and clarified the system to gather ideas through oral means, gestures, images, objects and symbols. Inprasitha (2010, 2011) presented the Open Approach that are consists of posing open-ended problems, student self-learning, whole class discussion, and summarize through connecting students' mathematical ideas emerged in the classroom, is a new approach to teaching mathematics that addresses problem solving, encourage students to take open-ended activities to observe students' learning skills by integrating to Lesson Study; Collaboratively Plan, Collaboratively 
Do, and Collaboratively See. So that, it's necessary to investigate what student learnt about speaking skills in the context of classroom using Lesson Study and Open Approach and consistent with skills in the twenty-first century.

\section{Learning Skills}

21st-century skills originated in the widely that will demand a very different set of skills and competencies from people in order to function effectively at work (Ananiadou \& Claro, 2009). These skills helped students to learn when they solved the problems, wrote their ideas on worksheets, presented their ideas, shared their ideas with their peers, and discussed ideas at the front of the classroom. Isoda, Morita, and Nobuchi (2009, cited in Inprasitha, 2014) identified the three learning skills as writing skills, speaking skills, and listening and questioning skills which were basic skills to solve the problems in a mathematics classroom. Among the identified learning skills, speaking skills are related to the behavior of communication using language that is coupled with listening. For communication to be complete, a listener must complement a speaker. Isoda, Morita, and Nobuchi (2009, cited in Inprasitha, 2014) was divided the levels of speaking skills into the following five;

Level one, composed of students speaking in a clear voice.

Level two, composed of students capable of speaking and presenting their ideas step by step.

Level three, composed of students able to speak with the use of pictures and tables to explain their reason.

Level four, composed of students who could link their reasoning to a previously learned subject.

Level five, composed of students capable of providing explanation using information that was useful and easy to understand, observing the condition of their peers to who me they spoke.

\section{Context of Study}

As shown in Figure 1, the Lesson Study implementation in Thailand, has

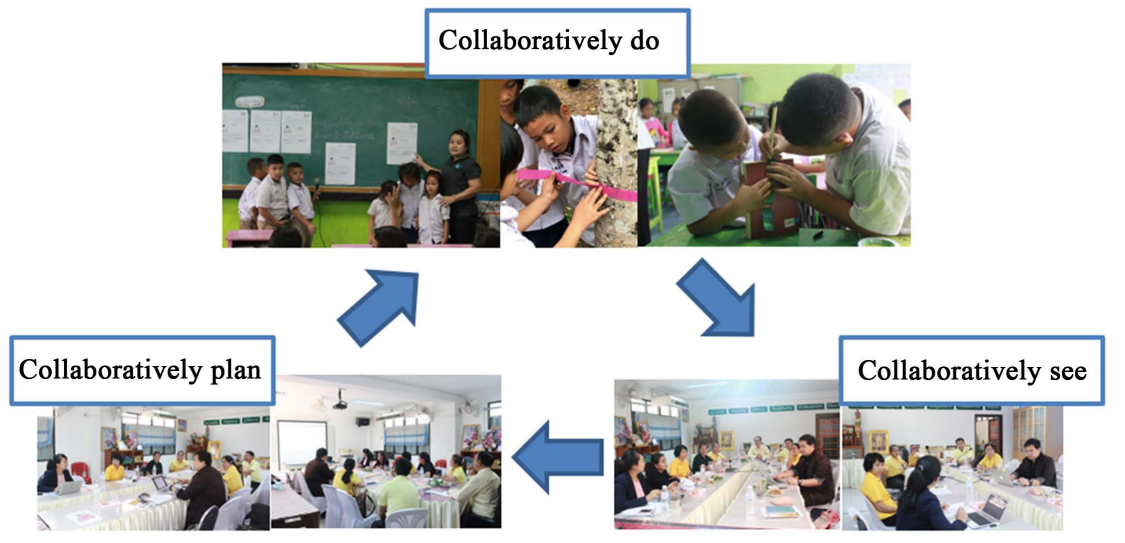

Figure 1. Lesson Study weekly cycle (Inprasitha, 2010, 2011, 2015). 
developed in teacher professional development which was three processes that teachers worked together with the goal of developing Thai mathematics instruction according to Inprasitha's conceptual framework $(2010,2011,2015)$ there are the following;

1) Collaboratively design a research lesson (Plan), lesson study teams that consisted of researcher, research assistants, teachers, experts and school principal designed lesson plan, chose the tools and content to teach as an open-ended problem, shared their ideas and effort, identifying open-ended math problems and learning activities. The problem situation is developed from mathematics textbook in teacher development project. In this research, they focused on students' learning skills.

2) Collaboratively observe the research lesson (Do), was an activity for using classroom plans that are planned by the Lesson Study teams; including researcher, research assistants, other observers observed students' ideas in Mathematics classroom. The main purpose of observing is to observe students "thinking processes, not to observe teachers" teaching skills. Focusing on students' responses to open-ended problems and how students' thought and presented.

3) Collaborative discuss and reflect on the research lesson (See), as an activity that the Lesson Study teams brought the results of classroom learning activities from classroom observation to a common discussion of classroom learning activities to improve learning management plans for use in other classes or to discuss ideas. Students' ideas occurred in the classroom so that Lesson Study teams have opportunity to reflect what they learnt from observation and teachers will reflect on students' speaking skills.

As shown in Figure 2, in mathematics classroom, Open Approach was used as a new mathematics teaching approach that focused on problem solving process and integrated to the Lesson Study according to the Inprasitha $(2010,2011)$ with consisted of four steps as follows;

1) Posing open-ended problem. In this research, they designed the length learning unit for the 1st grade students. Teacher posed open-ended problems situation that designed from Lesson Study teams. Teacher encouraged students to consider and checked problem situation.

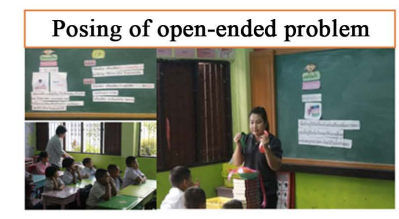

Summarize through connecting students' mathematical ideas emerged in the classroom
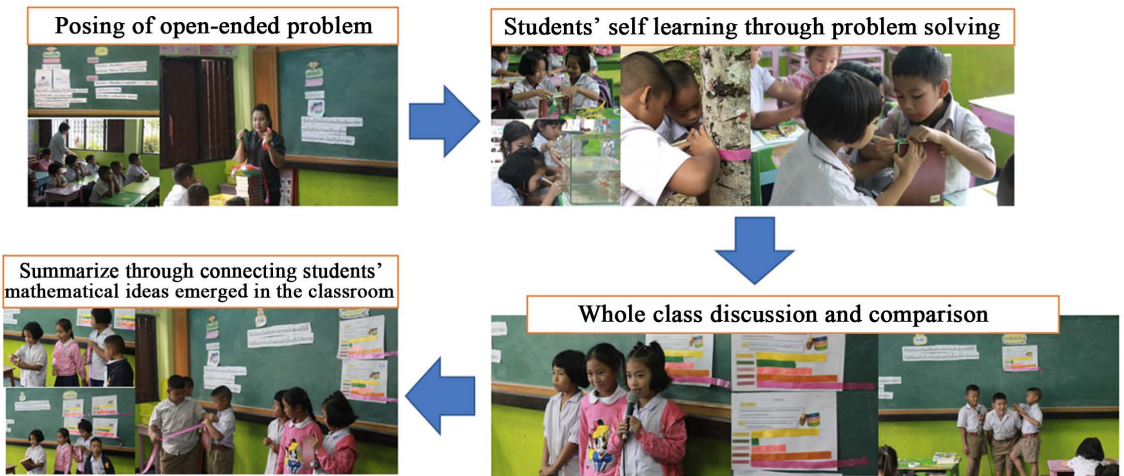

Figure 2. The four steps of Open Approach as a teaching approach in mathematics classroom (Inprasitha, 2010, 2011). 
2) Students self-learning through problem solving. After teacher posed open-ended problem situation, students tried to find how to solve the problems. They could organize activities into groups or single depends on what they designed the activity. In this phase, teacher gave opportunity for students to express their ideas freely. Students shared the ideas about what they think in their group.

3) Whole class discussion and comparison. After students solve this problem, they will present what they think in front of the class and others discuss together. In this phase, teacher must listen to what students presented and collected for next phase to discuss.

4) Summarization through connecting students' mathematical ideas emerged in the classroom. Teacher was responsible for collecting all the ideas that occur in the classroom and summarized the ideas together.

\section{Methodology}

\subsection{Target Group}

The target group was comprised of twenty-nine students in a first-grade in mathematics classrooms using Open Approach as a teaching approach. Target group was selected with purposive sampling. The students were same classroom and could work together. Their personality was expressive by talking to express their opinion, discussing, proposing their ideas in providing reason during they solved the problem. They volunteered to participate as a target group. They were assigned into group.

\subsection{Research Instruments}

In this research, the researcher used 2 kinds of research instruments: the instrument using for data collection, and the instrument using for data analysis, as follows:

1) Lesson plans in the length learning units that designed from Lesson Study teams. Lesson Study Teams collaboratively plan to focus on students' speaking skills.

2) Video recorder, camera, and audio tape recorder to collect the data when they used the lesson plan in the classroom.

3) Questionnaire about speaking skills from the teacher based on framework of Isoda, Morita, and Nobuchi (2009 cited in Inprasitha, 2014) that consisted of 5 levels after finished the classroom.

\subsection{Data Collection}

Data were collected in school year 2018 in Ban Dondaengcharoenthong school in Nakhon Phanom province in Thailand, a school under the project of development of advanced mathematical thinking of students in the area of the Northeast, Khon Kaen University. Collected date by using questionnaire about speaking skills based on framework of Isoda, Morita, and Nobuchi (2009 cited in 
Inprasitha, 2014) and classroom observation in the length learning units that designed from Lesson Study teams in the context of classroom using lesson study and open approach based on Inprasitha $(2010,2011)$.

\section{Results}

The research findings found that students' speaking skills in classroom using open Approach were as shown in Figure 3.

As shown in Table 1, the result of this research is as follows:

1) Level 1: Students who spoke in a clear voice (17.24\%).

2) Level 2: Students who could speak and present their own ideas step by step. $(51.72 \%)$

3) Level 3: Students who could speak with the use of pictures or tables to explain their reasoning. $(24.13 \%)$

4) Level 4: Students who could speak link between their reasoning and a previously learned subject. (3.45\%)

5) Level 5: Students could explain by using information that useful and easy to understand, observing the condition of the peers when they spoke. (3.45\%)

From Figure 3 and Table 1, the results of the research described the students' speaking skills in mathematics classroom using Lesson Study and Open Approach, revealed only five students in first-grade who were able to speak with a

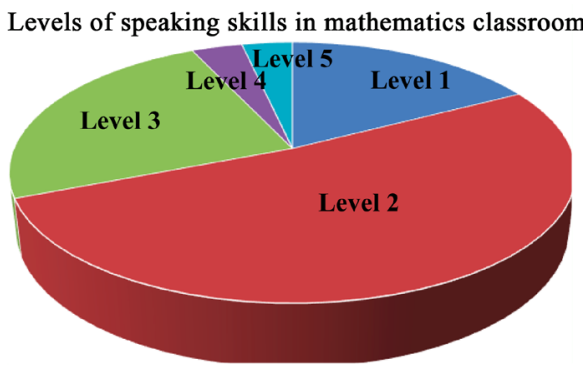

Figure 3. Levels of students' speaking skills in mathematics classroom using Lesson Study and Open Approach.

Table 1. The results of the assessment of students' speaking skills.

\begin{tabular}{|c|c|c|c|}
\hline Level & Items & $\begin{array}{l}\text { Total of } \\
\text { students }\end{array}$ & $\begin{array}{l}\text { Percentage } \\
\text { (s) }\end{array}$ \\
\hline 1 & Students spoke in a clear voice. & 5 & 17.24 \\
\hline 2 & $\begin{array}{l}\text { Students could speak and present their own } \\
\text { ideas step by step. }\end{array}$ & 15 & 51.72 \\
\hline 3 & $\begin{array}{l}\text { Students could speak by using pictures or tables } \\
\text { to explain the reason. }\end{array}$ & 7 & 24.13 \\
\hline 4 & $\begin{array}{l}\text { Students could speak link between their reason } \\
\text { and the subject what they learned before. }\end{array}$ & 1 & 3.45 \\
\hline 5 & $\begin{array}{l}\text { Students could explain by using information } \\
\text { that useful and easy to understand, observing the } \\
\text { condition of the peers when they spoke. }\end{array}$ & 1 & 3.45 \\
\hline
\end{tabular}


clear voice to present in front of the classroom. Most students could present their ideas and there were more than half of the students were able to speak to present their ideas in a sequence. Students expressed their ideas and explained clearly. In the design of activities by the Lesson study teams, there was a plan and design of learning materials for activities in problem situations.

Students used learning materials to solve the problems and presented ideas through learning materials, using the learning materials to find the solutions from problem situations. There were some students who could link how to learn in previous subject and used in this period and how to find the solutions and providing explanations with useful information that was easy to understand, further observing the condition of their peers when they spoke, thus demonstrating proficiency at the fourth and fifth levels.

As shown in Figure 4, the problem situation: yesterday, we compared the width and the length of mathematics textbook. Today, first, compare the width and the length of the desk by using one pencil and write their ideas on the worksheet. Second, compare the length between the pen and the pencil.

As shown in Figure 5, students compared what side is longer. In each group, they used learning materials prepared in the classroom to solve the problem in phase 2-students self-learning through problem solving of Open Approach.

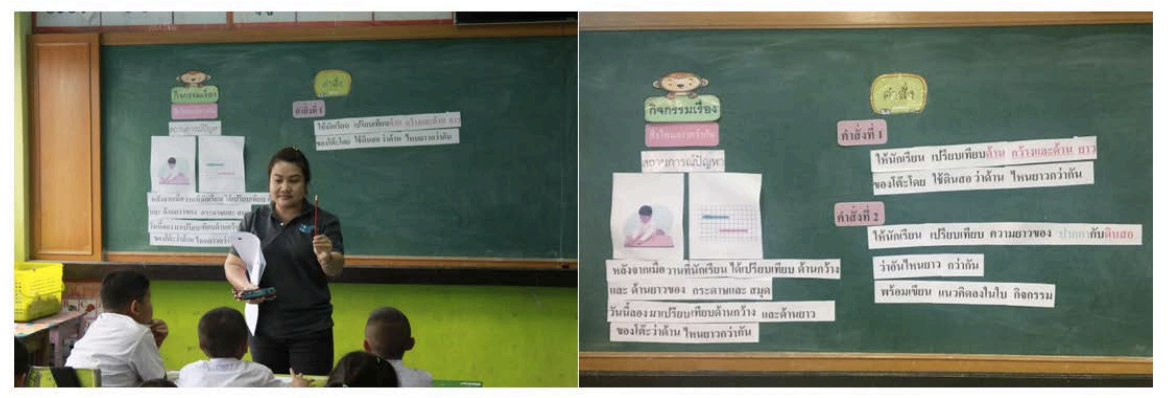

Figure 4. Evidence in mathematics classroom about students' speaking skill in the classroom in the length learning unit in grade 1, how to compare the length. Teacher posed open-ended problem situation that designed from Lesson Study teams in phase 1-posing open-ended problem of Open Approach (Inprasitha, 2010).

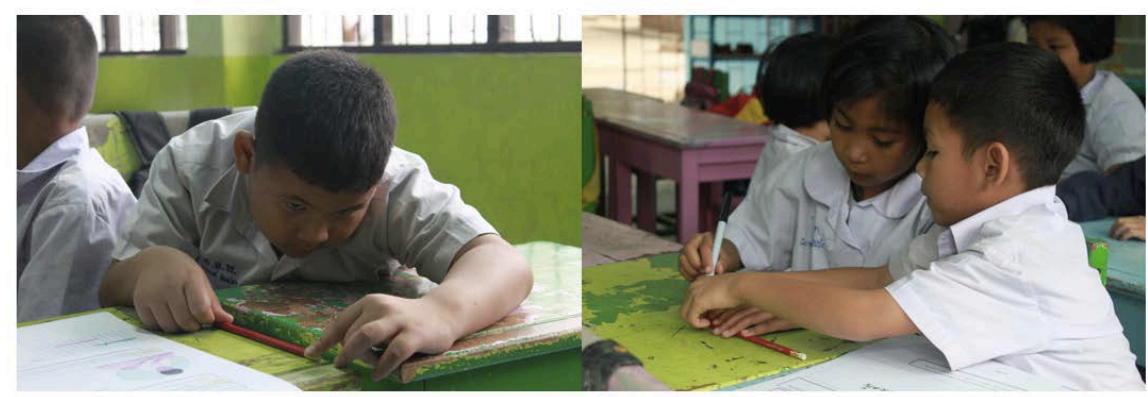

Figure 5. Students tried to solve how to find the width and the length of the desk in mathematics classroom using Lesson Study and Open Approach (Inprasitha, 2010). 
As shown in Figure 6, students checked together about what they wrote. Everyone is involved in the work. So that, when they presented in front of the classroom, everyone could present and describe about the worksheet in phase 2-students self-learning through problem solving of Open Approach.

As shown in Figure 7, after students solved the problem, every group must present how to solve the problem in front of the classroom. For this one they presented with a loud voice and explain by demonstrating how to find the solution to support their, in the first task, they said, "they used the pencil to measure the width of the desk is 3 pencils and the length is 2, so that they found the width is longer".

As shown in Figure 8, when students presented in front of the classroom, teacher could ask some questions for students to describe how to find the solution. Such as, this moment teacher asked "How do you know what side is 3" and students showed what they do and counted "one two three, so the answer is 3 ".

As shown in Figure 9, this group presented with a loud voice and shown how to compare the length between the pen and the pencil. They said "the pencil is longer than the pen is 2" and the teacher asked "Can you explain why the pencil is longer than the pen is 2, what is 2?" and student answer "they count from the square in worksheet, the pen is 5 squares and the pencil is 7 , so that it's longer than the pen is 2 squares".

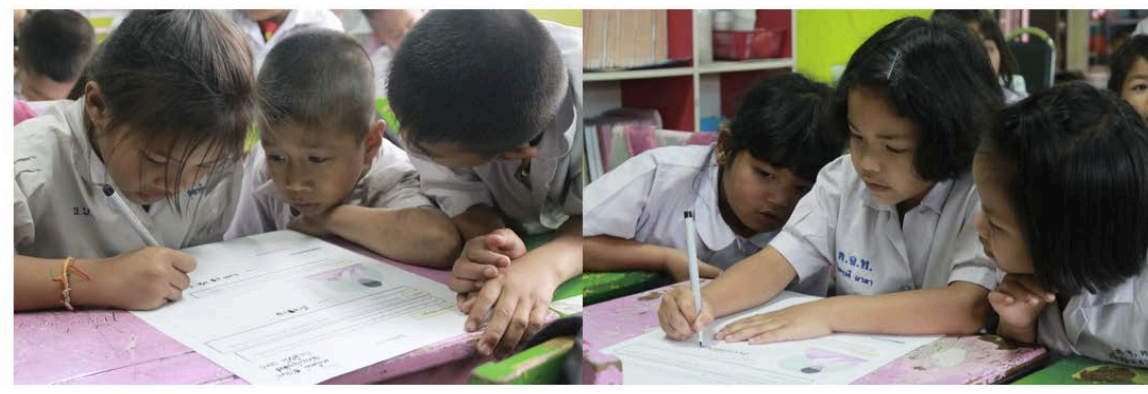

Figure 6. Each group of students, after they solved the problem they wrote their ideas on their worksheet in mathematics classroom using Lesson Study and Open Approach (Inprasitha, 2010).

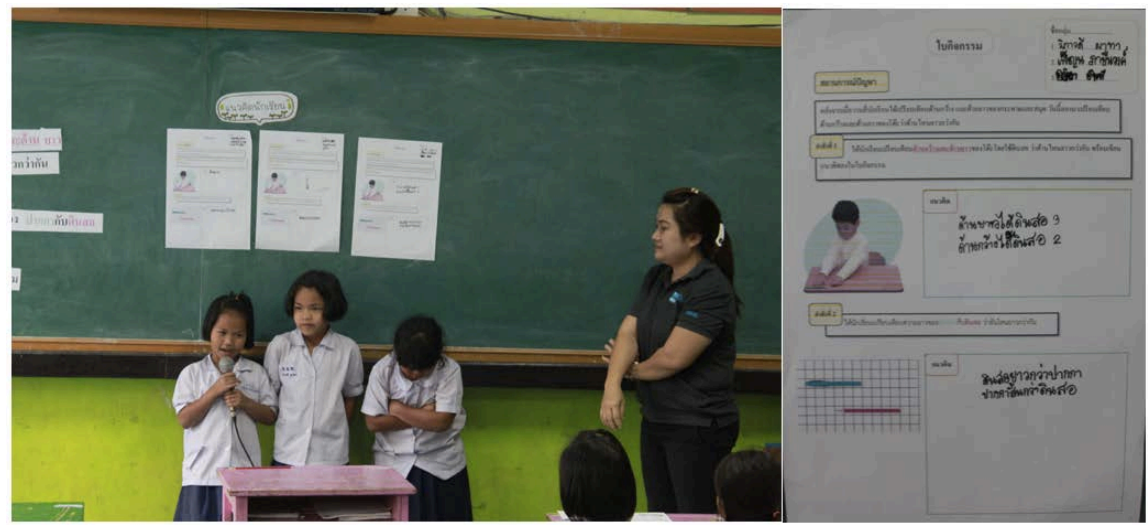

Figure 7. Each group presented in front of the classroom about how to solve the problem in phase 3-whole class discussion and comparison of Open Approach (Inprasitha, 2010). 


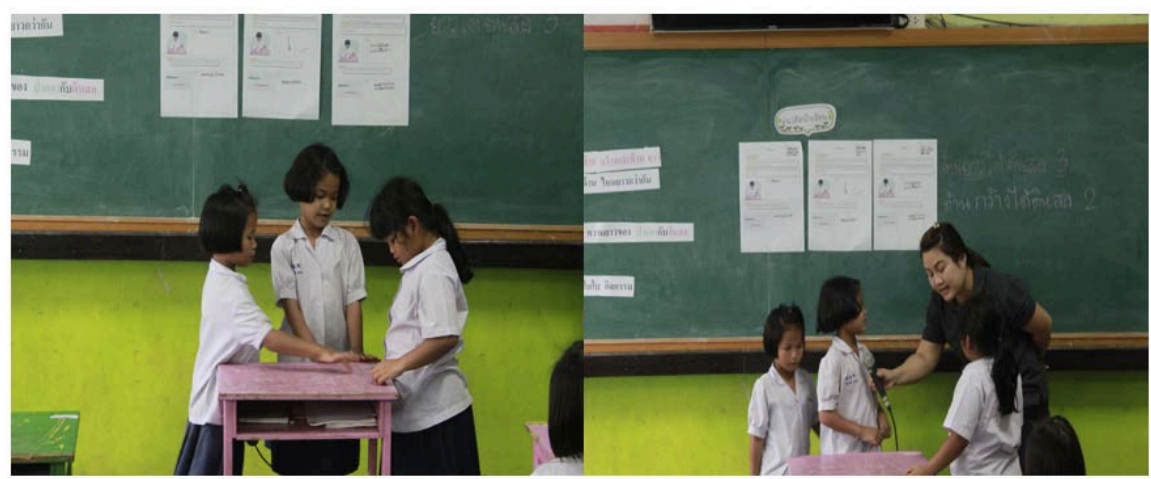

Figure 8. Students are shown how to measure the width and the length of the desk in phase 4-summarization through connecting students' mathematical ideas emerged in the classroom of Open Approach (Inprasitha, 2010).
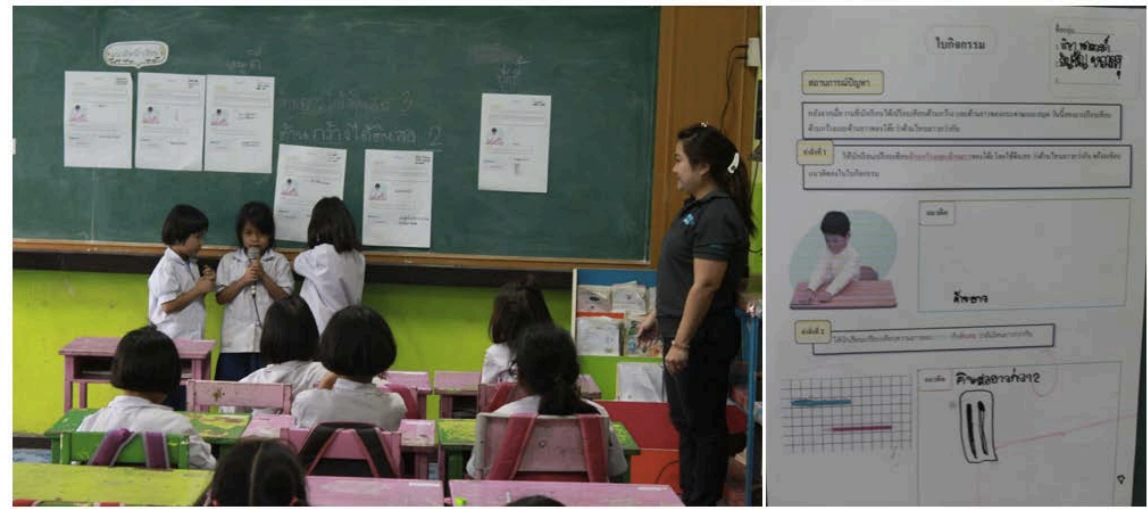

Figure 9. Students presented what they solved the second task "compare the length between the pen and the pencil." in phase 4-summarization through connecting students' mathematical ideas emerged in the classroom of Open Approach (Inprasitha, 2010).

As shown in Figure 10, worksheets from all groups will be stick in the blackboard that students saw all of worksheets and checked together about their peers presented in phase 4-summarization through connecting students' mathematical ideas emerged in the classroom of Open Approach.

\section{Discussions}

From the research findings above, more than half of students could speak and present their own ideas step by step in the classroom. It was clear their speaking skills included speaking loudly and speaking clearly during interactions between students with each other and interactions between students and their teacher during the problem-solving processes. In the activity, the teacher presented problem situations, requiring the students to complete the activity one by one followed by shared it in their group. Students exchanged ideas within the group by explaining their own ideas and sharing ideas by presentation at the front of the classroom. It was clear the students' speaking skills were at the first and second levels, and at level three, there were one-fourth of the students, demonstrating the ability to speak with the use of pictures and tables to explain their 


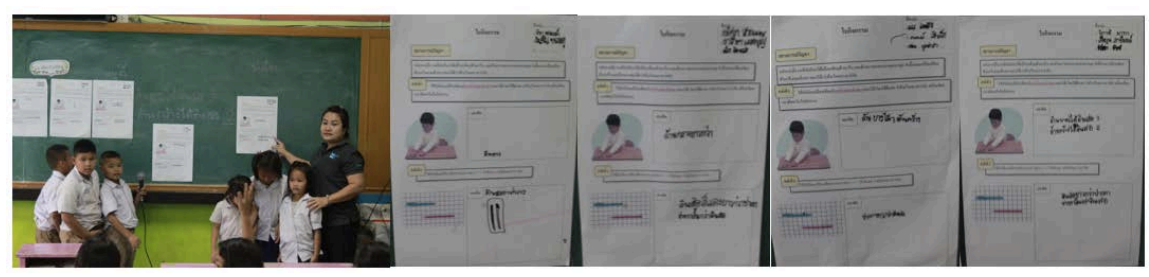

Figure 10. Teacher and students collaborated to summarize what they learned from their ideas and peers in mathematics classroom using Lesson Study and Open Approach (Inprasitha, 2010).

reasoning. Students represented pictures to describe their ideas, for example drawing a pencil to represent an actual pencil which they then used to measure the length of side of a desk by counting the number pencils needed to stretch the length of the desk for length in pencil. For the higher levels, only one student was capable of speaking to link between their reasoning and the previously learned subject, explaining with useful information easy to understand, and observing the condition of their peers when speaking. Their communication must support or stimulate them to do more in the next.

\section{Concluding Remarks}

This research was to investigate students' speaking skills in mathematics classroom using Lesson Study and Open Approach based on Isoda, Morita and Nobuchi's conceptual framework (2009, cited in Inprasitha, 2014) in the context of classroom using lesson study and open approach based on Inprasitha (2010, 2011). Lesson Study teams designed a learning activity, designed worksheets and discussed about the objective of each period for all students to learn and give opportunity to learn freely. The results of this research reveal the level of students' speaking skills. The highest level is level two: 54.72 percent-more than half of the total students were capable of presenting their ideas step by step. Approximately one fourth of the students occupied level three: 24.71 percent demonstrated the ability to speak with the use of pictures or tables to explain the reasoning. And another level, quite a low level must support students to higher levels. With an overview of this research, some students attempted to speak loudly and clearly. During the presentation, interacted with their friends and answered more questions from their friends and teacher. They could discuss ideas with their peers the ideas that arose in the classroom and explained the ideas through their own perspectives. So that, in this case was limitation of the study because it is shown in sampling group that school in school under the project of development of advanced mathematical thinking of students in the area of the Northeast, Khon Kaen University. In the further study, the researcher is interested in how to develop students' speaking skills to a higher level.

\section{Acknowledgements}

This research was granted by the Center for Research in Mathematics Education (CRME), Khon Kaen University, Khon Kaen, Thailand. 


\section{Conflicts of Interest}

The authors declare no conflicts of interest regarding the publication of this paper.

\section{References}

Ananiadou, K., \& Claro, M. (2009). 21st Century Skills and Competences for New Millennium Learners in OECD Countries. OECD Education Working Papers, No. 41.

Cedefop (2008). Terminology of European Education and Training Policy. A Selection of 100 Key Terms. Luxembourg: Office for Official Publications of the European Communities.

Gani, A. S., Fajrina, D., \& Hanifa, R. (2015). Students' Learning Strategies for Developing Speaking Ability. Studies in English Language and Education, 2, 17-30. https://doi.org/10.24815/siele.v2i1.2232

Inprasitha, M. (2004). Teaching by Open-Approach Method in Japanese Mathematics Classroom. KKU Journal of Mathematics Education, 1, 1-15.

Inprasitha, M. (2010). Teaching Professional Development in Thailand. Japan: Naruto University.

Inprasitha, M. (2011). One Feature of Adaptive Lesson Study in Thailand: Designing Learning Unit. Journal of Science and Mathematics Education, 34, 47-66.

Inprasitha, M. (2014). The Students' Mathematical Higher Thinking Development Project in Northeastern of Thailand. KhonKaen: Center for Research in Mathematics Education.

Inprasitha, M. (2015). Lesson Study: Challenges in Mathematics Education. Hackensack, NJ: World Scientific Publishing. https://doi.org/10.1142/7045

Inprasitha, M., Pattanajak, A., Treesirirat, J., \& Prasertcharoensuk, T. (2003). Reforming of the Learning Processes in School Mathematics with Emphasizing on Mathematical Processes. Thailand: KhonKaen Printing.

Isoda, M., Morita, M., \& Nobuchi, M. (2009). Problem Solving Approach: Standards for Teachers and Children. Japan: Meijitosyo Publisher.

Lee, C. (2006). Language for Learning Mathematics Assessment for Learning in Practice. New York: Open University Press.

Levy, F., \& Murnane, R. J. (2004). The New Division of Labor: How Computers Are Creating the Next Job Market. Princeton, NJ: Princeton University Press. https://doi.org/10.1515/9781400845927

Mart, C. T. (2012). Developing Speaking Skills through Reading. International Journal of English Linguistics, 6, 91-96. https://doi.org/10.5539/ijel.v2n6p91

National Capital Language Resource Center (2004). Elementary Immersion Learning Strategies Resource Guide (2nd ed.). Washington, DC: National Capital Language Resource Center.

National Council of Teachers of Mathematics (2000). Principles and Standards for School Mathematics. Reston, VA: NCTM.

Nombre, A. Y., Segura Alonso, R., \& de Junio, C. (2012). The Important of Teaching Listening and Speaking Skills. Máster en formación del profesorado de, Educación Secundaria Obligatoria.

Pourhossein, A. (2014). Classroom Interaction and Development Speaking Skill. Department of English Language, Science and Research Balances. 